\section{Dizry of Societies.}

\section{FHIDA $Y$, November 18.}

A ssociation of Colono Brolonists (ut Imperial College of science) (Botany Dopartnme), at 2.15.-Foot and Mouth Disease :-F.'C. Minett: History ; Foot and Month Disease in Farm Auimals; Disinfection.Tr. A. Arkwight: Experimental Foul and Mouth Disease in Small Animals; General Characters of the Virus; Imrnunity.-Dr. S. P. Bedson: Phy sical Properties of the Virus, Filtration, etc.; Prophylactic Vaccines.-Mrs. Y. M. Burbury: Survival of the Virus Outside the
Body.-I. A. Galloway: Demonstration of the Lesions of Foot and Body.-I. A. Galloway : Dent
Mouth Diseaso in Guinea-Pigs.

\section{SATURDAY, NOYEMERR 19}

British Mycolonical Society (at University College), at 11.-S. F. Ashby: The Oospores of Phytophthore nicotiane, with Notes on the Taxonomy of $P$. parasitica. - B. F. Barnes: On the Production of Variations in Hurotium.-S. Garside: Method of Reproduction in Siphula tabularis. -R. M. Nattrass: The Physalospora Disease of Basket Willow. - J. Ramsbottom: Myeological Nomenclature. Eliturial Oomments

INSTITURe of British Foundry men (Lancashire Branch-Junior Section (in Mauchester University), at 3.-Prof. F. O. Thompson : Address.

Hopa. Institution of Gagat Britain, at $3 ., \mathrm{G}$. Holsi: Samuel Wesley and Robert Pearsall (I.).

Hull Association of Eraineers (at Municipal Technical College, Hull) at 7.15. - Prof. G. Stoney : Modern Practice in Steam Turbines.

\section{MONDAY, NOVFMBER 21.}

institution of Mrchanical. Engineers (Graduates Section, London), at 6.80.-G. K. Wood: The Locomotive Boiler in Service.

Institution of Electrical ENGINeERs (intormal Meeting), at $7 .-$ W. Day and others: Discussion on Automatic Teleptiony.

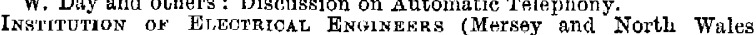

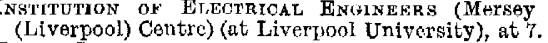

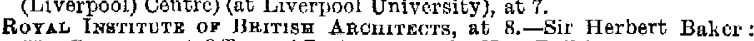

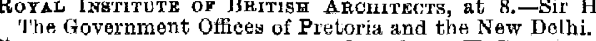

Rotal Socirty of A RTs, at 8.-Prot, H. C. H. Carpenter: Alloy steels, their Manufacture, Properties, and Uses (Cantor I,tetures) (II.).

RoYal GEOGRAPHICAL SOCIETY (at Aolian Hall), at 8.30.- Major R. E. Chessman: The Blue Nile.

Chamioal lndustiry Chub.

\section{TUESDAY, NOVEMBER 22.}

ROYaL InBTITUTION OF GReat Britals, at 5.15. - Sir William Bragg: a Year's Work in X-Ray-Crystal Analysis (I.).

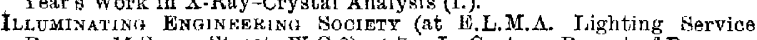
Bureali, 15 Savoy Street, W.C.2), at 7.-L. Gaster: Report of Progress during the Vacation. - Report of Committee on Progress in Electric Lannps and Jighting Appliances. - H. Talbot: Progress in Gas Lighting. - At 6,15 - Wxhibition of Recent Lighting Appliances.

Royal Protographic Society of GrFa't BerTaIN (Colour Group), at 7.-.F. G. Newmareh: Some of my Experiences in Colour Work.

INSTITUTION OF FNoINER AND SHIPBUIIDERS IN SCOTLAND (at 39 Elmbank Crescent, Glasgow), at $7.30, \cdots-6$. H. Faris: The Uses of Nickel T)eposits for Engineering Purposes.

Sonery of Glass Technolowy (at Congregational Schoolroom, Stourbridge), at 7.30.-l'rot, W. E. 8. Turner: Modern Artistic Glass (Lecture).

TNSTITUTION OF AUTOMOBILE ENGKNRRs (jointly with institute of Traus. port) (at Institution of Heotrical Engineers), at 8.-Capt. C. If. Kuhne: Military Transport Vehicles : Recent Development and their Commercial Significance.

RoYAl ANTHROPOIOnICAL INSTITUte, at 8.30. - The Misses French Where the Graat Wall Ends.

WEDNESDAY, NOVEMBER 23.

INGTITUTE of FUEL (Anumal Meeting) (at Institution of Hilectrical

Faranay Sootety (at Cliemical Society), at 2.30.-Gencral biscussion on Cohesion and Related Problems, Introductory 8urvey by Prof. O. H. lesch, and Papers by the following:-N. K. Adan, H. J. Gongh, A. A. Griffith, Prof. B. P. Haigh, sir W. 13. Hardy, Prof, A. Joffe, Prof. J. E. Jennard Jomes, J'rof. M. Polanyi, Prof. A. W. Porter, Joffe, Prof. J. F. Lemard Jomes, Jrof. M. Polanyi, Prof. A. W. Porter,

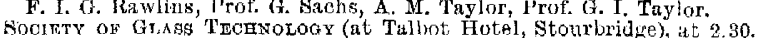

-M. H. Edwards: Firc Olays as applied to tho Glass industry.-
- H. Prof. W. L. D. Turner: Glass. Pot Manufacture in Great Brituin. Mrs. G. A. Green (Edith M. Firth) and Prop. W. E. S. Turmer: The Homogeneity of GIass Melted in Pots.-- Dr. S. English, H. W. Howes, and P'ruf. W. E. S. Purner: Tha leffect of Iron Oxide on the Properties of Glass.

Royal Institute of Public Hralth, at 4.-Dr. D. Fordyce: The Provention of Ifeart Disease.

Royar. Society of Menicine (Comparative Medicine Section), at 5 Dr. E. Obermer: The Endwrinology of Tuberculosis.

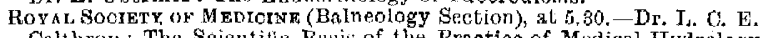
Calthrop: The Scientifie Basis of the Practice of Medical Hydrology (Y'rosidential Address).

INGTiTUtion OF Automonile Enainaers (North of England Centre) (at Finginetrs'. Olub, Manehester), at 7.-U, B. Thylor: High-Speed Com. pression-Ignition Engine Research.

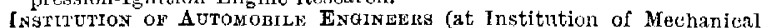
lingineers), at 7.45.-H. L. Hornung: The Trend of Design in Motor Trucks and yotor Coaches for Fleet operation. Royal Instipute of British Akchitects, at 8.-M. S. Briggs: The

Roval SocIrrY or ArTs, at 8.-T. H. Barry : Malayan Varnish Resins.

No. 3029, VoL. 120]
Royar. AEnonauthal Snetety (Manehester Branoh) (jointly with Manchester Branch of Institulion of Aeronantical Engineers).-H. B. Taylor: The Design and Development of the Compression-Ignition Engine.

THURSDAY, NOVEMBR. 24

INSTITUSE OF FURL (Annual Meeting) (at Institution of Electrical En. gineers), at 10.30 A.M.

Eifetrical association ror Women (at 155 Regent Street, W.), at 3.The Value ol a Refrigerator in Winter (Lecture).

Royal INgTitution of GrEAT Britain, at 5.15.-Dr. R. E. M. Whecler: London before the Norman Conquest (II.).

Royal AEnovatrical. Soomery, at 6.30.-Major C. J. Stewart: Modern

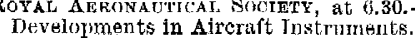

OHEMical Society, at 8.-Prof W. $\Lambda$. Bone: Gaseous Combustion at HEMICAL SocieTy, at 8.--
High Pressures (Lecture).

Royal Socinty or MEDisine (Disease in Children, Therapentics, and Urology Sections), at 8.50.--Special Discussion on The Treatment of Pyuria in Children.

Medico.Legal Society (at 11 Clandos street, W.), at 8.30.-Capt. N. Parlies: A Oase of Pathological Drunkenness as a Defence of Insanity at a Murder Trial.

Society of Chemical Introstry (Jirmingham and Midland section) (at Chamber of Commerce Buildings, Birmingham). - A. R. Warnes : Notes on the Chemistry and Physics of Stome Decay.

Instriturion of 'THE Rumber InDUstry (Manchester Section) (at Assembly Roorns, Blackfrides IIouse, Manchestar).-Major A. B. Shearer: Arti. ficial Silk and its Use in the Rubber Trade and P'ossible lines of Development.

$$
\text { FRIDAY, NOVEMBER 25. }
$$

Parsical Society (at Imperial College of Science), at 5.-A. E. Knowler: The Electrical Resistance of Porous Materials.-K. Kichlu : Regularities in the Spectrum of Ionised Neon.-Dr. Ezer Griffiths: A Calorimoter for tho Measurement of the Heat Developer by Fruit.NatrTution of Electrical HNankera (London Students' Section), at $6.15 .-\mathrm{G}$. H. Wilson: Sources of tllumination.

Manchesten Literatix and Phicosch'pical Society (Chemical Section) (at Manchester), at 7.

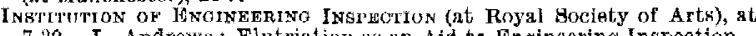
7,30.--I. Andrews : Elntriation as an Aid to Enginoning Inspeotion. Junior Institution of ENaINEers, at 7.30.-L. P. Perkins : A Talk about l'ioneers in High Pressure Steam.

Royal Society or Mvicine (Epidemiology Section), at 8.-Dr. E. H. R. Hairies: Immunity in the Making.

Drasel Excine Users' Assocration (at Caxton Hall).-J, E. Hurst: CrESEL EACINE UsERs AsSOCraTION (at Cax

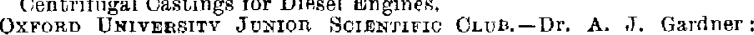
Lecture.

SATURDAY, NOVEMUER 26.

Royal Ingtitution of Great Britain, at 3.-G. Holst: Samuel Wes!ey and Robert Pearsall (II.).

\section{PUBLIC LECTURES.}

SATURLAY, NOVEMBER 19

Horniman Museum (Vorest Hill), at 3.30.-H. N. Milligan : Common Mistakes about Evolution.

MONDAY, NovEMBER 21.

Goldsmirirg' Hate (Fuster Lane, 19,C.2), at 4,- Very Rev. Dean Inge

Scientific Ethics (Norman Lockyer Lccture).
UNiversity or LEDDs; at 5.15.-Dr. R. A. Fisher: Mathematics and UNIVERSITY OF LIEDS;
Theories of Evolution.

KIN's Colfews, at 6.80.-Prof. Doris Livingston Mackinnon: Throngh a Glass Darkly.

loast Angitian Institute of AgRicultune (Cholmsford), at 7.-Prof. R. G. Stapledon: The Growing of Pedigres: Strains of Grasses and Clover for seed.

TURSDAY, November 22.

Roval Bocintry of Awds, at 8.15.-Major H. Barnes; The llistory of Housing: Housing 1885 to 7027 (Chadwick Lecture).

\section{WHDNESDAY, NOVEMEER 23 .}

Krna's Coulaom, at 5.30.--E. Sulter Tavies: Secondary Lducation: Technical [nstitutes, Evening Bchnols, and Day Continuation Srhosels. University College, at $5.30,-\mathrm{C}$. 0 . G. Douie: The Report of the llepartmental Commitiee on Libraries.

pandon School of liconomics, at $6 .-$ H. Coleman: Office Machinery : The Numeralpha Filing System and the Roneodex Visible Index System.

TIURSDA $Y$, NOVEMBKK 24 ,

Chaniva Cnoss Lospital, at 3.- Sir Archibald Garrod: Recent Advances in Science in relation to Medicine and surgery (IIuxley Lectire).

FTLIDAY, NoveMrer 25 .

Krag's Colleat at 5.80.-C. J. Gadd: The Beginnings of the City of Ur.

SATURDAY, NOVEMBER 20.

Horniman Museum (Forest Hill), at 3.30.-J. J. S. Dallas: Nature in the Alps,

\section{CONGRESS.}

Dechamer 15 ro 24.

Journéges Méducales v'Egypte (at Cairo). 